\title{
Southern Cabbageworm (larva), Checkered White (adult) Pontia (=Pieris) protodice (Biosduval \& Leconte) (Insecta: Lepidoptera: Pieridae: Pierinae) ${ }^{1}$
}

Donald W. Hall ${ }^{2}$

\section{Introduction}

Pontia protodice (Boisduval \& Leconte), formerly Pieris protodice Boisduval, is a common pierid butterfly throughout much of the United States that may be locally abundant. The larva which is occasionally found on crop plants in the family Brassicaceae is known as the southern cabbageworm. This is the accepted name for this species in the Entomological Society of America's Common Names of Insects \& Related Organisms list, and is the name most often found in books on economic entomology (Capinera 2001, Cranshaw 2004, Metcalf and Metcalf 1993).

However, the species is known uniformly in butterfly books by the common name of the adult --the checkered white (Allen 1997, Brock and Kaufman 2003, Cech and Tudor 2005, Daniels 2003, Glassberg et al. 2000, Minno et al. 2005, Opler and Krizek 1984, Scott 1986, Wagner 2005). This is also the common name used in the North American Butterfly Association's Checklist of North

\begin{abstract}
American Butterflies Occurring North of Mexico. Therefore, the name checkered white is used in this publication.
\end{abstract}

\section{Distribution}

The checkered white is resident in most of the southern U.S., but also colonizes northern states and occasionally parts of southern Canada. It is most common in disturbed areas where its favored host plants occur. Wagner (2005) states that while the checkered white was once abundant, its populations have plunged along the eastern seaboard from New England to the Carolinas, and it is now local or rare in these areas. He raised the question of whether its decline in these areas may be due to Cotesia glomerata (Hymenoptera: Braconidae) or other introduced biological control agents. It is still common along roadsides and in other disturbed areas of central Florida.

\footnotetext{
1. This document is EENY-434, one of a series of Featured Creatures from the Entomology and Nematology Department, Florida Cooperative Extension Service, Institute of Food and Agricultural Sciences, University of Florida. Published: February 2009. This document is also available on Featured Creatures Website at http://creatures.ifas.ufl.edu. Please visit the EDIS Website at http://edis.ifas.ufl.edu. Additional information on these organisms, including many color photographs, is available at the Entomology and Nematology Department website at http://entnemdept.ifas.ufl.edu/.

2. Donald W. Hall, professor, Entomology and Nematology Department, Cooperative Extension Service, Institute of Food and Agricultural Sciences, University of Florida, Gainesville, FL 32611.
}

The Institute of Food and Agricultural Sciences (IFAS) is an Equal Opportunity Institution authorized to provide research, educational information and other services only to individuals and institutions that function with non-discrimination with respect to race, creed, color, religion, age, disability, sex, sexual orientation, marital status, national origin, political opinions or affiliations. U.S. Department of Agriculture, Cooperative Extension Service, University of Florida, IFAS, Florida A. \& M. University Cooperative Extension Program, and Boards of County Commissioners Cooperating. Millie Ferrer, Interim Dean 


\section{Description}

Adults: The wing spread of adults is 1.25 to 2.00 inches (Daniels 2003). Males are white with charcoal markings on the front wings. Females are grayish-white with darker gray or charcoal checkered markings on both front and hind wings. Early spring and late fall (cool season) adults tend to be smaller, darker, and more heavily patterned (Daniels 2003).

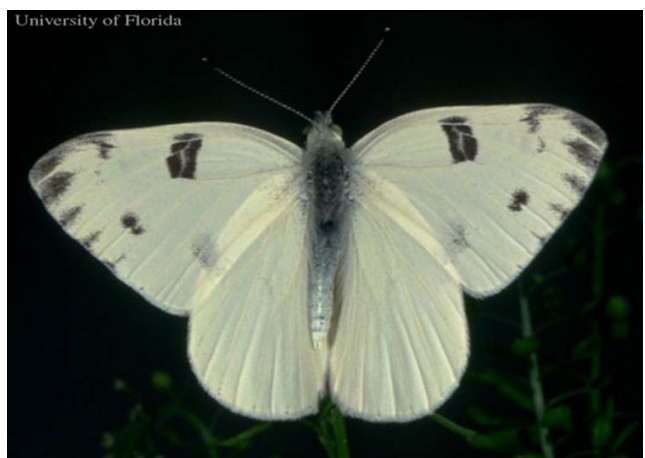

Figure 1. Adult male checkered white butterfly, Pontia protodice (Boisduval \& Leconte). Credits: J.F. Butler, University of Florida

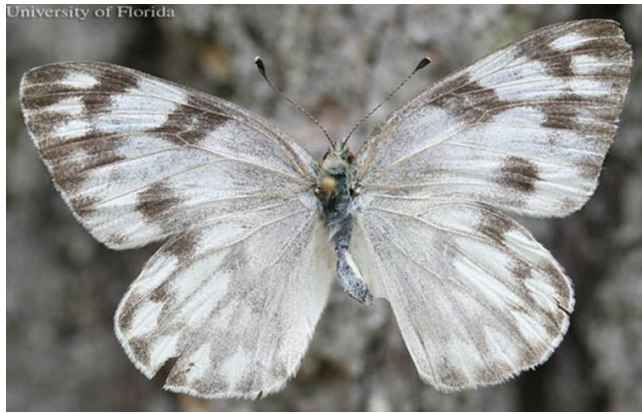

Figure 2. Adult female checkered white butterfly, Pontia protodice (Boisduval \& Leconte). Credits: D.W. Hall, University of Florida

Eggs: Eggs are yellowish when first laid but later change to orange. They are barrel-shaped, tapered at the apex and have longitudinal ridges.

Larvae: Full grown larvae are approximately $1.1 "$ in length. The head is gray with yellow patches; the body is gray with yellow stripes, rows of small black spots and numerous short hairs (Minno et al 2005).

Pupae: The pupae are bluish-gray with mid-dorsal and lateral white stripes and small black dots on the ventral half of the body. The pupae are attached by a cremaster and a silk girdle

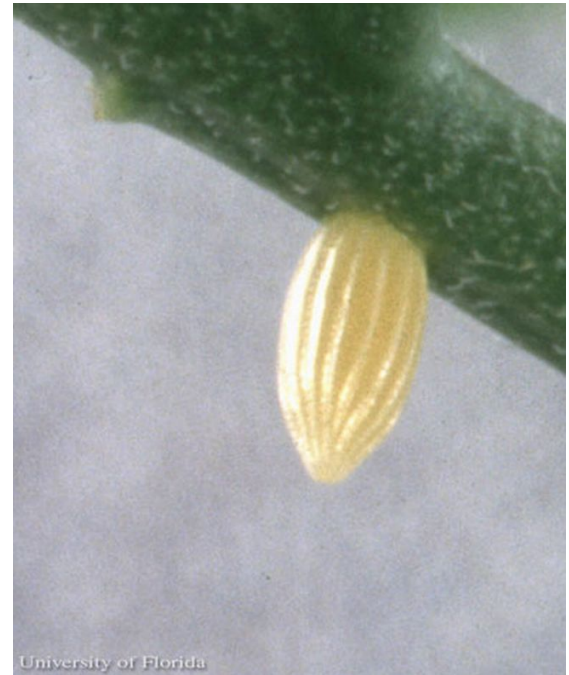

Figure 3. Egg of the checkered white buttefly, Pontia protodice (Boisduval \& Leconte). Credits: J.F. Butler, University of Florida

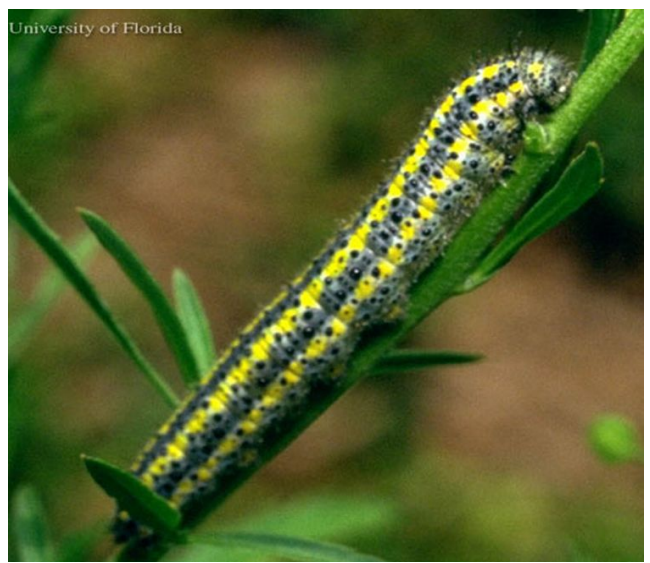

Figure 4. Larva of the checkered white buttefly, Pontia protodice (Boisduval \& Leconte). Credits: J.F. Butler, University of Florida

\section{Life Cycle and Biology}

Adult checkered whites take nectar from a variety of flowers. Tooker et al. (2002) cited a study by $\mathrm{C}$. Robertson in Illinois in which adult checkered whites were observed to feed on nectar from flowers of over 50 species of plants.

Although adults are sexually dimorphic in terms of dark pigmentation of the wings, both sexes recognize the opposite sex by differential UV reflectivity rather than by differences in the dark pigmentation (Rutowski 1981). When adult populations are dense, a female is typically mated during its first day of adult life and may mate more than once during its lifetime. Dense populations where there are numerous male/female interactions 


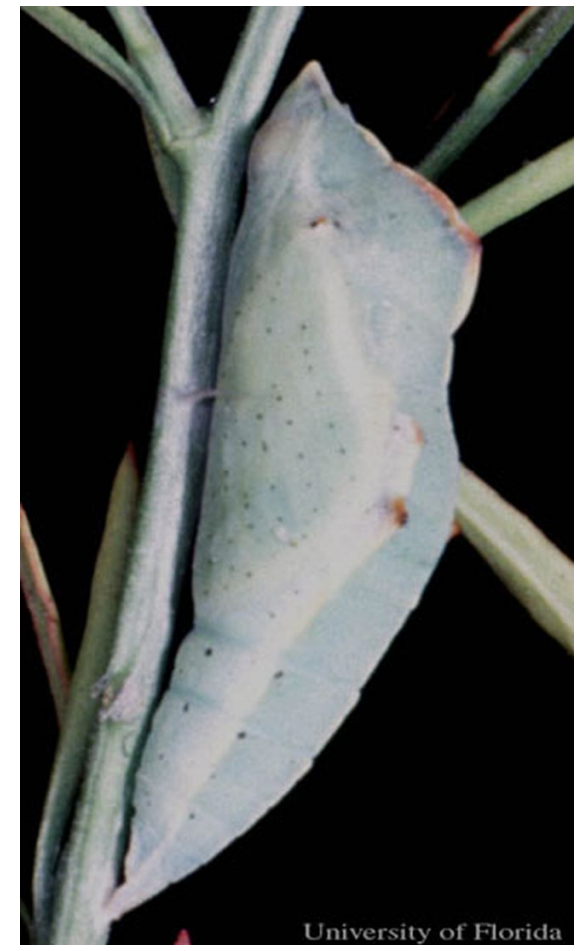

Figure 5. Pupa of the checkered white buttefly, Pontia protodice (Boisduval \& Leconte). Credits: D.W. Hall, University of Florida

act as a signal for females to migrate to less densely populated areas (Shapiro 1970).

During mating, a male passes a spermatophore that represents about 7 to $8 \%$ of his body weight and requires about 24 hours to regenerate his potency while a female requires about five to seven days to deplete the contents of the spermatophore (Rutowski 1984). Males, because of their large investment, tend to select younger and larger females for mating (Rutowski 1982).

Females assess the egg load of host plants prior to oviposition. Eggs are often laid on the fruits of host plants but may also be laid on stems. Larvae prefer flowers or fruits but will also eat leaves of the host plants (Minno et al. 2005).

\section{Host}

The hosts of checkered white larvae are herbs in the mustard family (Brassicaceae). Preferred hosts are Virginia pepperweed (Lepidium virginicum L.) in the Southeast and prairie pepperweed (Lepidium densiflorum Schrad.) in the North, but they also eat the exotic shepherd's purse (Capsella bursa-pastoris [L.] Medik.) (Miller and Miller 1970).

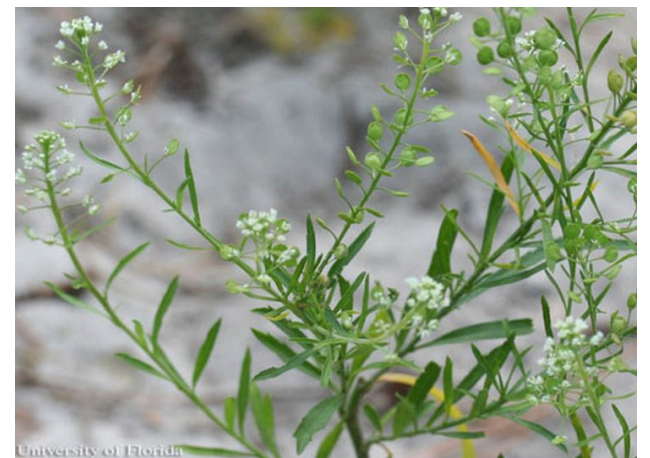

Figure 6. Virginia pepperweed, Lepidium virginicum L., a host of the checkered white buttefly, Pontia protodice (Boisduval \& Leconte). Credits: D.W. Hall, University of Florida

\section{Economic Importance}

Checkered white larvae are occasionally minor pests on cultivated members of the mustard family (Brassicaceae) including cabbage, broccoli (Kok and McAvoy 1989, Reid and Cuthbert 1971), and horseradish (Marsh 1913). On cabbage, the larvae eat only the outer leaves in contrast to larvae of the cabbage white butterfly (imported cabbageworm), Pieris rapae (Linnaeus) which bore into the heads (Scott 1986).

If required, control measures for checkered white larvae in Florida are listed in the Insect Management Guide for crucifers.

\section{Selected References}

- Allen TJ. 1997. The Butterflies of West Virginia and their Caterpillars. University of Pittsburgh Press. Pittsburgh, Pennsylvania. 400 pp.

- Brock and Kaufman 2003. Butterflies of North America. Houghton Mifflin Company. New York, New York. 383 pp.

- Capinera JL. 2001. Handbook of Vegetable Pests. Academic Press. San Diego, California. 729 pp.

- Cech R, Tudor G. 2005. Butterflies of the East Coast: An Observer's Guide. Princeton University Press. Princeton, New Jersey. 345 pp.

- Cranshaw W. 2004. Garden Insects of North America. Princeton University Press. Princeton, New Jersey. 656 pp. 
- Daniels JC. 2000. Butterflies 2: Butterflies of the Southeast. UF/IFAS. Card Set. SP 274.

- Daniels JC. 2003. Butterflies of Florida: Field Guide. Adventure Publications, Inc. Cambridge, Minnesota. 256 pp.

- Entomological Society of America. (2008). Common Names of Insects \& Related Organisms.

http://www.entsoc.org/Pubs/Common_Names/ (21 May 2008).

- Glassberg J, Minno C, Calhoun JV. 2000. Butterflies through Binoculars: Florida. Oxford University Press. New York, New York. 256 pp.

- Kok LT, McAvoy TJ. 1989. Fall broccoli pests and their parasites in Virginia USA. Journal of Entomological Science 24: 258-265.

- Marsh HO. 1913. The horse-radish web-worm. USDA Bureau of Entomology Bulletin 109 (pt vii): 71-76. (Also lists $P$. protodice as pest of horse radish).

- Metcalf RL. Metcalf RA. 1993. Destructive and Useful Insects: Their Habits and Control. 5th ed. McGraw-Hill, Inc. New York, NY. 1200 pp.

- Miller LD, Miller JY. 1970. Pieris protodice and Urbanus dorantes in southern Florida. Journal of the Lepidopterists Society 24: 244-247.

- Minno MC, Butler JF, Hall DW. 2005. Florida Butterfly Caterpillars and their Host Plants. University Press of Florida. Gainesville, Florida. $341 \mathrm{pp}$.

- Opler PA, Krizek GO. 1984. Butterflies East of the Great Plains. The Johns Hopkins University Press. Baltimore, Maryland. 294 pp.

- North American Butterfly Association. (2004). Checklist of North American Butterflies Occurring North of Mexico. http://www.naba.org/pubs/enames2.html (21 May 2008).
- Reid Jr WJ, Cuthbert Jr FP. 1971. Control of caterpillars on commercial cabbage and other cole crops in the South. Farmer's Bulletin (2099) 24 pp.

- Rutowski RL. 1981. Sexual discrimination using visual cues in the checkered white butterfly Pieris protodice. Zeitschrift fuer Tierpsychologie 55: 325-334.

- Rutowski RL. 1982. Epigamic selection by males as evidenced by courtship partner preferences in the checkered white butterfly Pieris protodice. Animal Behaviour 30: 108-112.

- Rutowski RL. 1984. Production and use of secretions passed by males at copulation in Pieris protodice (Lepidoptera: Pieridae). Psyche (Cambridge) 91(1-2): 141-151.

- Scott JA. 1986. The Butterflies of North America: A Natural History and Field Guide. Stanford University Press. Stanford, California. $583 \mathrm{pp}$.

- Shapiro AM. 1970. The role of sexual behavior in density-related dispersal of pierid butterflies. The American Naturalist 104 (No. 938): 367-372.

- Tooker JF, Reagel PF, Hanks LM. 2002. Nectar sources of day-flying Lepidoptera of central Illinois. Annals of the Entomological Society of America 95: 84-96.

- Wagner DL. 2005. Caterpillars of Eastern North America. Princeton University Press. Princeton, New Jersey. 512 pp. 